\title{
Main musculoskeletal injuries associated with lameness in Chilean Rodeo horses
}

\author{
Principales afecciones musculoesqueléticas asociadas a claudicación \\ en equinos del rodeo chileno
}

\author{
M Mora-Carreno ${ }^{\mathrm{a}}$, R Briones ${ }^{\mathrm{a}}$, JS Galecio ${ }^{\mathrm{a}}$, D Parra ${ }^{\mathrm{b}}$, C Rosenfeld ${ }^{\mathrm{c}}$, A Schmeisser ${ }^{\mathrm{d}}$, B Menarim ${ }^{\mathrm{a}}$ \\ anstituto de Ciencias Clínicas Veterinarias, Facultad de Ciencias Veterinarias, \\ Universidad Austral de Chile, Valdivia, Chile. \\ ${ }^{\text {b} C l i ́ n i c a ~ V e t e r i n a r i a ~ L a s ~ T r o y a s, ~ T a l a g a n t e, ~ C h i l e . ~}$ \\ 'Instituto de Medicina Preventiva Veterinaria, Facultad de Ciencias Veterinarias, Universidad Austral de Chile, Valdivia, Chile. \\ ${ }^{\mathrm{d}}$ M.V. F.E.I., Práctica Privada, Osorno, Chile.
}

\begin{abstract}
RESUMEN
El rodeo es la disciplina ecuestre más popular en Chile. Se estima que las afecciones musculoesqueléticas de los equinos participantes son la principal causa de enfermedad y bajo desempeño de estos, sin embargo no existen reportes relacionados. El objetivo de este estudio fue determinar y caracterizar las principales afecciones asociadas a claudicación en caballos del rodeo chileno. Se realizó un estudio retrospectivo considerando registros de atenciones clínicas de ejemplares participantes del rodeo chileno que presentaron claudicación. Se recopiló información referente a 114 casos, incluyendo la identificación (nombre, edad y sexo) y las características clínicas de cada episodio. La edad promedio de los equinos fue de $8 \pm 3,4$ años. El 98,3\% $(n=112)$ de los episodios correspondieron a claudicaciones espontáneas, siendo $2 / 4$ el grado de claudicación más frecuente. El 72,8\% (83/114) de los casos fueron claudicaciones unilaterales, afectando mayormente a miembros anteriores (51/83). Los diagnósticos más frecuentes fueron desmitis del ligamento suspensor (14\%), osteoartritis társica distal (13,2\%), síndrome navicular (8,8\%), laminitis (7,9\%), tendinitis del flexor digital profundo (7\%) y osteoartritis metacarpofalángica $(6,1 \%)$. La alta frecuencia de claudicaciones espontáneas de grado 2 sugiere que una parte importante de las atenciones veterinarias se realizan en una etapa más severa de la afección. Lesiones articulares, podales y tendinoligamentosas parecen ser las principales causas de claudicación en equinos de rodeo chileno. Estos resultados sugieren que medidas de educación respecto de la importancia de realizar diagnósticos precoces y mayor cuidado de los cascos son medidas primarias a favor de la profilaxis de claudicación en estos ejemplares.
\end{abstract}

Palabras clave: rodeo chileno, claudicación en equinos, lesiones musculoesqueléticas, caballo chileno.

\section{SUMMARY}

Chilean Rodeo is the most popular equestrian discipline in Chile and it is estimated that musculoskeletal diseases of the equine participants are the leading cause of illness and poor performance, however no related reports have been published. The aim of this study was to identify and characterize the main diseases associated with lameness in Chilean Rodeo horses. A retrospective study was performed considering the clinical attention records of horses participating in Chilean Rodeo which presented lameness. Information was collected regarding 114 cases, including identification (name, age and gender) and the clinical characteristics of each episode. The average age of the horses was $8 \pm 3.4$ years. Among the subjects, $98.3 \%$ of the episodes corresponded to spontaneous lameness, with $2 / 4$ being the most frequent degree of lameness. Unilateral episodes corresponded to $72.8 \%$ (83/114) of the cases, affecting primarily the front limbs (51/83). The most frequent diagnoses were: suspensory ligament desmitis (14\%), tarsal osteoarthritis (13.2\%), navicular syndrome (8.8\%), laminitis (7.9\%), deep digital flexor tendonitis (7\%) and metacarpophalangeal osteoarthritis (6.1\%). The high frequency of grade 2 lameness suggests that the majority of veterinary attentions seem to be mostly at obvious conditions. Joint, foot and soft tissue conditions seem to be the main cause of lameness in equines participating in Chilean Rodeo. These results suggest that education regarding the importance of early diagnosis and greater hoof care are primary measures that may favor the prevention of lameness in Chilean Rodeo horses.

Key words: Chilean Rodeo, horse lameness, musculoskeletal injuries, Chilean Horse.

\section{INTRODUCTION}

Competition-related sport horse injuries are currently a major financial burden in the equine industry. Lameness has been identified as the most prevalent condition in horses, affecting all breeds, ages, disciplines and genders (Kane

Accepted: 09.05.2014.

* Casilla N 567, Valdivia, Chile; brunomenarim@uach.cl et al 2000, Ross 2003 a). In the U.S. it is estimated that annual losses due to early retirement of equine athletes is between 678 million and 1 billion dollars (Seitzinger et al 2000). However, there is no such information for the Chilean Horse and Rodeo industry.

As the level of equine competition increases, the athletic demand causes patterns of musculoskeletal injuries associated with the various sports disciplines. Identification, management and prevention of injuries in equine athletes requires a great understanding of the demands of each 
discipline, and the way these injuries manifest in order to minimize the financial loss they cause in the equine industry (Dyson 2000). Veterinarians must be familiar with their patient's breed, activity and the physical demands of the competition, as the prognosis of musculoskeletal injuries varies drastically between different disciplines and levels of competition (Ross 2003a).

Chilean Rodeo is a very popular sport in Chile, in which the Chilean Horse is the only breed allowed to compete. It is performed in a circular 20 to $25 \mathrm{~m}$ radius arena ${ }^{1}$, divided into two parts: a half moon shaped arena called medialuna (figure 1A) and an elliptical small pen called apiñadero (starting arena) (figure 1A, marker a). Inside the apiñadero, a pair of riders waits for a steer to be released to chase it, guiding it through two complete clockwise runs around the walls. This event demands sudden accelerations, turns and stops at high speed, all within a confined space. Once this run is completed, the riders and steer exit through the left door of the apiñadero into the medialuna. One horse goes behind the steer and chases it while the other guides it by performing a lateral gallop to the further padded wall through the borderline of the main arena, this is in order to complete the three atajadas (figure 1B). These atajadas describe when one of the horses charges the steer and pins it against the padded wall in a fast and precise movement. The first and last atajadas are on the right pad (figure 1A, marker $\mathrm{b}$ ) and the second on the left pad of the medialuna (figure 1A, marker c). Points are scored for adequately driving the steer in the arenas, for the pins, and also for which part of the steer's body is pinned by the horse ( 3 points for hitting the flank; 2 points for hitting the chest; 1 point for hitting the shoulder).

Although Chilean Rodeo is a highly popular and much practiced sport throughout the country, creating a substantial industry, there is not much information regarding causes of equine attrition, differing to equine industries in some other countries (Kane et al 2000, Seitzinger et al 2000, Ross $2003^{b}$ ). As musculoskeletal diseases are the most common cause of attrition in athletic horses, and due to the fact that there is a lack of information regarding the causes of lameness in Chilean Rodeo, the aim of this study was to determine and characterise the most important musculoskeletal injuries associated with lameness in Chilean Rodeo horses.

\section{MATERIAL AND METHODS}

Clinical records of horses examined by 3 veterinarians between 2000-2010 were considered. Horses belonged to breeding farms from Central (Metropolitan) and Southern areas of Chile, and were attended by one of three veterinarians involved in this study. Records of acute or chronically

1 http://www.youtube.com/watch?v=z-0gAsL2Rig (consulted on 20/03/2013)
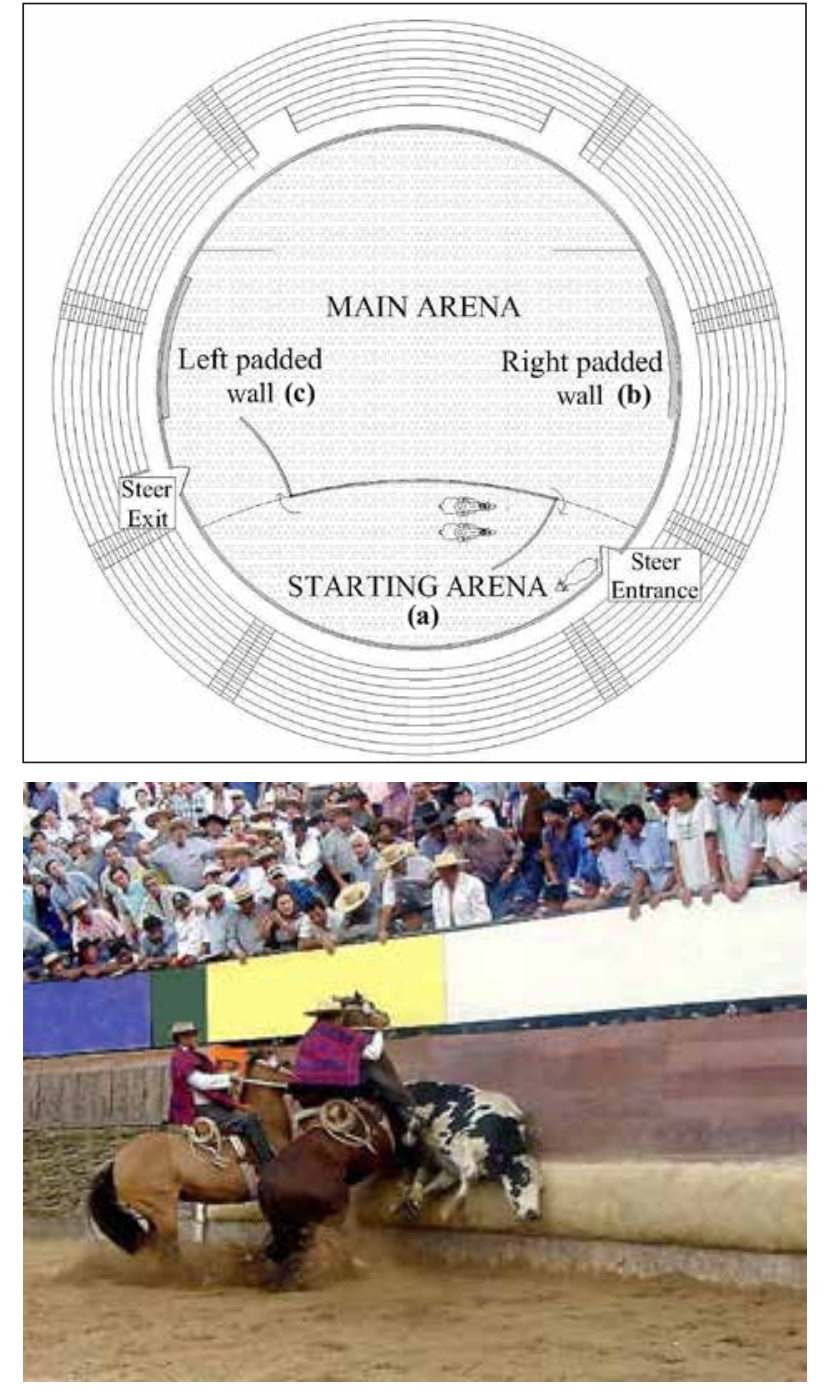

Figure 1. A: Diagram of a Medialuna used in Chilean Rodeo competitions (a: starting arena, place of beginning of the competition where the riders must guide the steer to accomplish two complete clockwise runs. b: right padded wall, where the first and last catches are performed. c: left padded wall, where the second catch is performed). B: Picture of a typical atajada (catch). Source: A) Personal authorship; B) Google ${ }^{2}$.

A: Diagrama de una medialuna utilizada en competencias de rodeo chileno (a: apiñadero, lugar de inicio de la competición donde la dupla de jinetes debe guiar al novillo a dar dos vueltas completas en sentido del reloj. b: quincha derecha, donde se realiza la primera y última atajada del novillo. c: quincha izquierda, donde se realiza la segunda atajada del novillo). B: Fotografía de una atajada.

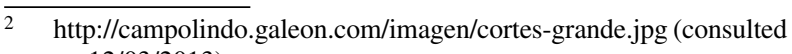
on $12 / 03 / 2013$ )

lame Chilean Horses under training for, or performing in Chilean Rodeo competitions were examined.

Information obtained from clinical records included: name, age, gender, date of veterinary attention, affected $\operatorname{limb}(\mathrm{s})$, degree of lameness and diagnosis. As horses begin training for Chilean Rodeo no sooner than four years of 
age, data of horses under this age were excluded to avoid including lesions not necessarily related to athletic activity.

Lameness diagnosis: horses were evaluated at walk or trot in a straight line, as well as during rodeo exercise in some cases. Clinical examinations considered inspection, limb palpations and manipulation, use of hoof testers, forced flexion and diagnostic analgesia. Lameness was scored on a scale of $0-4(0=$ sound, $4=$ not weight bearing $)$, according to Stashak (1985), through an observation of the horse in movement before and after forced flexion. Gaits were also classified in spontaneous lameness, when the horse was lame independently of circumstances or lame just after forced flexion. Radiographic and ultrasound evaluations were performed for each particular case according to the requirements of the attending veterinarian.

Statistical analysis: in order to determine the injuries that most frequently caused lameness in the studied population, data from each horse was entered into a MS EXCEL $®$ calculus sheet for descriptive statistical analysis based on arithmetic mean and standard deviation. Chi square tests, with SPSS version 17.0 for Windows (SSPS Inc, Chicago IL, USA), were performed to determine significant differences regarding lameness distribution between limbs.

\section{RESULTS}

\section{POPULATION CHARACTERISATION}

Records of horses aged 4-19 years old (Average \pm $\mathrm{SD}, 8 \pm 3.4)$ were examined. Gender distribution was: females $(53 \%, \mathrm{n}=60)$, geldings $(26 \%, \mathrm{n}=30)$ and stallions $(21 \%, \mathrm{n}=24)$.

\section{LAMENESS CHARACTERISATION}

During a 10 year period 114 lameness examinations were performed on 110 horses injured during athletic activity due to Chilean Rodeo. Four horses sustained more than 1 unrelated injury during the study period. Lameness was most frequently scored as grade 2 followed by grade 1 (table 1). Unilateral lameness was more common (72.8\%) than bilateral lameness (24.6\%) (table 2).

When comparing the distribution of lameness between forelimbs (FLs) and hind limbs (HLs), forelimb (FL) lameness was the most common. Of all unilateral lameness episodes, $61.5 \%(51 / 83)$ was present in one of the FLs, while the rest $(38.5 \%$; 32/83) was present in HLs (P $<0.05)$. When comparing frequency of distribution between right and left sides, no significant difference was observed between FLs $(\mathrm{P}>0.05)$ or between HLs $(\mathrm{P}>0.05)$.

\section{RECORDED DIAGNOSIS}

A large number of different diagnoses resulted from the 114 lameness examinations. The most frequent causes of lameness were: suspensory ligament desmitis (SLD) (14\%,
Table 1. Frequency and percentage of lameness scores (LS) distribution in 114 cases of lameness in Chilean Rodeo horses.

Frecuencia y distribución porcentual de los grados de claudicación (LS) en 114 casos de claudicación en equinos del rodeo chileno.

\begin{tabular}{lccc}
\hline \multicolumn{1}{c}{ Type of presentation } & LS & $\mathrm{n}$ & $\%$ \\
\hline Spontaneous & 1 & 32 & 28.0 \\
& 2 & 49 & 43.0 \\
& 3 & 19 & 16.7 \\
After forced flexion & 4 & 12 & 10.6 \\
\hline
\end{tabular}

Table 2. Frequency and distribution of the affected limbs in 114 cases of lameness in Chilean Rodeo horses.

Frecuencia y distribución porcentual de los miembros afectados en 114 casos de claudicación en equinos del rodeo chileno.

\begin{tabular}{lcc}
\hline \multicolumn{1}{r}{ Affected limb } & $\mathrm{n}$ & $\%$ \\
\hline LFL & 28 & 24.6 \\
RFL & 23 & 20.2 \\
LHL & 18 & 15.8 \\
RHL & 14 & 12.3 \\
LFL+RFL & 19 & 16.7 \\
LHL+RHL & 9 & 7.9 \\
LFL+RFL+RHL & 1 & 0.9 \\
LFL+RFL+LHL+RHL & 2 & 1.8 \\
\hline
\end{tabular}

(LFL: Left forelimb, RFL: Right forelimb, LHL: Left hindlimb, RHL: Right hindlimb).

(LFL: miembro anterior izquierdo, RFL: miembro anterior derecho, LHL: miembro posterior izquierdo, RHL: miembro posterior derecho).

16/114), exclusively in FLs and mostly unilateral (13/16); tarsal osteoarthritis $(\mathrm{OA})(13.1 \%, 15 / 114)$, representing $1 / 3$ of registered lameness in HLs and mostly unilateral (8/15); navicular syndrome (NS) (8.7\%, 10/114), affecting only FLs, with 6 unilateral cases and 4 bilateral; laminitis $(7.9 \%, 9 / 114)$, mostly bilateral in FLs (7/9); deep digital flexor tendonitis (DDFT) $(7 \%, 8 / 114)$, only unilateral and in FLs; metacarpophalangeal OA $(6.1 \%, 7 / 114)$, with 4 unilateral and 3 bilateral cases (table 3 ).

\section{DISCUSSION}

\section{POPULATION CHARACTERISATION}

The average age $(8 \pm 3.4$ years $)$ of horses presenting with lameness in this study was similar to that reported by Deppe et al (1994) studying podotroclear disease in Chilean Horses. This can be explained by the athletic peak in Chilean Rodeo horses being around this age, which leads to an increase in physical demand and risk of presenting musculoskeletal injuries (Porte et al 1994). Gender distribution of the horses (53\% females, 26\% geldings and $21 \%$ stallions) is also similar to what Deppe et al (1994) observed and in agreement with general equine sports, 
Table 3. Frequency and percentage distribution of main diagnosis in 114 lameness cases of Chilean Rodeo horses.

Frecuencia y distribución porcentual de los principales diagnósticos en 114 equinos del rodeo chileno que presentaron claudicación.

\begin{tabular}{lc}
\hline Diagnosis & $\mathrm{n}(\%)$ \\
\hline SLD & $16(14.0)$ \\
OA tarsus & $15(13.2)$ \\
ND & $10(8.8)$ \\
Laminitis & $9(7.9)$ \\
DDFT & $8(7.0)$ \\
OA MCP & $7(6.1)$ \\
\hline
\end{tabular}

(SLD: suspensory ligament desmitis, OA: osteoarthritis, ND: navicular disease, DDFT: deep digital flexor tendonitis, MCP: metacarpophalangeal joint).

(SLD: desmitis del ligamento suspensor del nudo, OA: osteoartritis, NS: síndrome navicular, DDFT: tendinitis del tendón flexor digital profundo, MCP: articulación metacarpofalángica).

where it's unusual for lameness to affect one gender more than the other (Ross $2003^{b}$ ).

\section{LAMENESS CHARACTERISATION}

Most recorded cases (98.2\%) were of spontaneous lameness, grade 2 being the most frequent, what differs of data from reference equine medical centers in Europe and North America, where the major part of the caseload is represented by horses presenting decreased performance or inconsistent lameness (grade 1) (Stricklin 1997, Dyson 2000, Jackman 2001, Lewis 2001). These differences can occur due to the fact that in countries with a better-developed equine industry, horse owners are better informed and aware of the importance of routine veterinary visits for early diagnosis in order to ensure musculoskeletal health and prolong athletic ability of their horses. In Chilean Rodeo horses, the higher presentation of grade 2 lameness could be explained by owners unable to identify or perhaps ignoring mild lameness, postponement of veterinary attention to avoid expenses or absence of urgency for treatment during the Chilean Rodeo off-season (April-August).

The differences found regarding higher lameness percentages in FLs than in HLs $(\mathrm{P}<0.05)$, are similar to those observed in most equine disciplines and are due to weight bearing close to $60 \%$ of their body on FLs (Boswell et al 2003, Ross 2003a , Stashak 2004a). Despite a tendency for left limbs to be more commonly affected, no significant difference in lameness distribution between the right limbs and left limbs was observed $(\mathrm{P}>0.05)$. Although increased presentation of left or right limbs has been reported in other disciplines, such as barrel racing and race horses, in which horses tend to compete in the same pattern or direction of the track (Peloso et al 1994, Stricklin 1997, Galley 2001), recent data from different training yards in the UK demonstrate these findings are not consistent, and some tendencies observed in lameness or specific injury patterns were attributed to the gait laterality of each horse (Ramzam and Palmer 2011). Chilean Rodeo horses alternate the stress on their limbs every other catch and every other run when they compete, thus probably favoring more homogenous distribution of workloads between the limbs.

\section{RECORDED DIAGNOSIS}

The prevalence of $\operatorname{SLD}(14 \%, \mathrm{n}=16)$ amongst injuries related to lameness onsets in this study was similar to those described for barrel racers (13\%) (Dabareiner et al $2005^{\mathrm{a}}$ ), a discipline with limb stress similar to those of Chilean Rodeo horses regarding biomechanical demands, with sudden changes of speed, sharp turns and quick stops during the competition (Stricklin 1997). Risk factors related to occurrence of SLD include conditions that generate hyperextension of the metacarpophalangeal joint, leading to over stretching of the ligament fibers during the impact phase of the stride. Predisposing causes of SLD include unbalanced shoeing, poor conformation, poor quality of work surface, intense competition schedules and overtraining (Stricklin 1997, Lewis 2001, Jackman 2001, Scott 2008), situations that are also present in Chilean Rodeo.

The second most common cause of lameness in this study was tarsal OA $(13.2 \%, \mathrm{n}=15)$, representing one out of three cases of lameness in the HLs. Such findings were also described by Mendoza (2008), who determined that the majority of the radiographic findings related to OA in Chilean Rodeo horses were in the tarsal region (81.5\%). A high incidence of tarsal OA have also been reported in show jumpers and some western work horses in which there is high biomechanical stress on the tarsus due to repetitive impact, compression and articular rotation, leading to inflammation and OA (Galley 2001, Jackman 2001, Lewis 2001, Boswell et al 2003, Scott 2008). The tarsi of Chilean Rodeo horses are subjected to high levels of stress caused by quick accelerations, stops and highly demanding lateral movements. In addition, the body weight appears to be supported by the HLs during the catch. Also, according to Vergara (2012), when studying conformational defects of competing Chilean Rodeo horses, 60\%-76\% had abnormal HLs conformation, another predisposing factor for tarsal OA.

ND was observed in the FLs of 10 horses (8.8\%). The average age of horses affected with ND was 8.5 years old, the age of its highest prevalence in equine athletes (Stock et al 2004) and similar to previously reported (Deppe et al 1994). In western disciplines it's related to small sized hooves in relation to heavily muscled bodies (Galley 2001, Scott 2008), a very frequent condition in Chilean Rodeo horses (Deppe et al 1994). It must be pointed out that factors such as conformation defects, unbalanced hooves, inappropriate and irregular shoeing predispose the horses to, and worsen this condition (Stashak 2004 ${ }^{\mathrm{b}}$ ) 
by generating higher biomechanical demands on the podotroclear apparatus (Scott 2008), conditions frequently observed in Chilean Rodeo horses.

Laminitis incidence in ponies, such as the Chilean Horse ( $7.9 \%$ in this study), is frequently caused by overfeeding of carbohydrates or grazing lush pasture (McDiarmid 2003, Treiber et al 2006). According to the observations of the authors, a predisposing factor for the disease in this special breed, specifically in obese middle-aged to old horses, is Equine Metabolic Syndrome, whose main clinical manifestation is chronic laminitis (Stewart 2011). In southern Chile, where most Chilean Horse breeding centers are located, the high incidence of laminitis can also be explained by the high concentration of Lolium sp., which contains a large amount of soluble carbohydrates in the forage in this area of the country (Stewart 2011). Although it's not a sport-related disease, some cases presented with laminitis for the first time within our period of study or recrudesced from a chronic well-managed condition. During competition, Chilean Horses are commonly overweighting and overfed due to esthetical principles (observation of the authors).

Lameness associated with DDFT was observed in 8 horses (7\%), presented unilaterally and exclusively in FLs. Lesions of the DDFT as a cause of lameness is commonly observed in competitions such as Show Jumping, Calf Roping and Team Roping, presumably as a result of sharp repetitive turns (Smith and Goodship 2004, Wilderjans and Boussauw 2007), maneuvers commonly performed by Chilean Rodeo horses. Additionally, it has been shown that a high percentage of horses with ND, the third most prevalent injury in this study, is associated with DDFT injuries adjacent to the podotroclear apparatus (Dyson 2011). The high prevalence of injury of the DDFT in comparison to the superficial digital flexor tendon, as observed in other breeds (Dahlgren 2009), can be explained by Chilean Rodeo horses not experiencing as much muscle fatigue as Thoroughbreds (Bertone 2004). A recent study (Vergara 2012) reported that the shoeing intervals for most Chilean Rodeo horses is approximately 45 days; as a result, many of these horses have low heels and long toes which creates a condition that predisposes the deep digital flexor tendon to injury (Dahlgren 2009).

Seven cases of lameness were associated with metacarpophalangeal joint OA $(6.1 \%)$, similar to the 5.9\% observed in horses used for Team Roping competitions (Dabareiner et al $2005^{\mathrm{b}}$ ). Although this joint has the highest range of movement, the presentation of this injury could be associated with a small joint surface absorbing impact during constant accelerations and sudden stops when driving and catching the steer, leading to stress overload on the articular cartilage and adjacent structures (Charlotte et al 1999, Bertone 2004).

Each veterinarian's individual results did not correlate completely with the overall rank of diagnosis in this study, despite the evaluation criteria being exactly the same in each case. These differences in results can be attributed to how each veterinarian approached each case and consequently which imaging sources were used and how these sources were interpreted.

Results of this study indicate that most lame Chilean Rodeo horses suffer from injuries of FLs. The most observed lameness grade (2/4) indicates that most lame horses are presented for evaluation when lameness is easily observed. Injuries such as suspensory ligament desmitis, tarsal osteoarthritis and navicular disease seem to be the primary causes of lameness in Chilean Rodeo horses and perhaps the prevention of these diseases should be a primary focus of study. The results of this study also suggest that education regarding the importance of early diagnosis and proper hoof care in order to improve limb biomechanics are primary measures that may favor prevention of lameness in Chilean Rodeo horses.

\section{REFERENCES}

Abellanet I. 2009. La terapia de lesiones de tejidos blandos y articulaciones con plasma rico en plaquetas en caballos de deporte: evidencias clínicas y bioquímicas que validan su utilización. Tesis Doctoral, Universidad Autónoma de Barcelona, Barcelona, España.

Bertone AL. 2004. Distal limb: Fetlock and Pastern. In: Hinchcliff KW, Andris JK, Raymond JG, Warwick B (eds). Equine Sports Medicine and Surgery: Basic and Clinical Sciences of the Equine Athlete. Elsevier Limited, Philadelphia, USA, Pp 130-151.

Boswell RP, RD Mitchell, SJ Dyson. 2003. Lameness in the Show Hunter and Show Jumper. In: Ross MW, SJ Dyson (eds). Diagnosis and Management of Lameness in the Horse. WB Saunders, Philadelphia, USA, Pp 965-975.

Charlotte E, L Cantley, E Firth, J Delahunt, D Pfeiffer, K Thompson. 1999. Naturally occurring osteoarthritis in the metacarpophalangeal joints of wild horses. Equine Vet J 31, 73-81.

Dabareiner R, N Cohen, G Carter, S Nunn, W Moyer. 2005ª Musculoskeletal problems associated with lameness and poor perfomance among horses used for barrel racing: 118 cases (2000-2003). J Am Vet Med Assoc 227, 1646-1650.

Dabareiner R, N Cohen, G Carter, S Nunn, W Moyer. 2005 ${ }^{\mathrm{b}}$. Lameness and poor performance in horses used for team roping: 118 cases (2000-2003). J Am Vet Med Assoc 226, 1694-1699.

Dahlgren LA. 2009. Management of tendon injuries. In: Robinson NE, Sprayberry KA (eds). Current Therapy in Equine Medicine. $6^{\text {th }}$ ed. WB Saunders-Elsevier, Missouri, USA, Pp 518-523.

Deppe M, R Tamayo, R Deppe. 1994. Algunas características de la enfermedad navicular (EN) en caballos chilenos atendidos en el Hospital Veterinario de la Universidad Austral de Chile. Arch Med Vet 26, 29-34.

Dyson SJ. 2000. Lameness and Poor Performance in the Sports Horses: Dressage, Show jumping and horse trials (Eventing). AAEP Proceedings 46, 308-315.

Dyson SJ. 2011. Navicular disease. In: Ross MW, Dyson SJ (eds). Diagnosis and Management of Lameness in the Horse. $2^{\text {nd }}$ Edition. WB Saunders, Philadelphia, USA, Pp 324-342.

Galley RH. 2001. Injuries of the team roping horse. AAEP Proceedings $47,15-21$

Jackman BR. 2001. Common lameness in the cutting and reining horse. AAEP Proceedings 47, 6-11.

Kane A, J Traub-Dargatz, W Losinger, L Garber. 2000. The Occurrence and Causes of Lameness and Laminitis in the U.S. Horse Population. AAEP Proceedings 46, 277-280.

Lewis RD. 2001. Lameness in the rodeo horse. AAEP Proceedings 47, 1-5. 
McDiarmid A. 2003. Lameness in the Pony. In: Ross MW, Dyson SJ (eds). Diagnosis and Management of Lameness in the Horse. WB Saunders, Philadelphia, USA, Pp 1069-1076.

McIlwraith CW. 2004. Enfermedades de las articulaciones, los tendones, los ligamentos y las estructuras relacionadas. En: TS Stashak (ed). Claudicación en el Caballo. $5^{\mathrm{a}}$ ed. Editorial Inter-Médica, Buenos Aires, Argentina, Pp 469-684.

Mendoza RG. 2008. Estudio radiográfico de lesiones de las extremidades de equinos atendidos en el Hospital Veterinario de la Universidad Austral de Chile durante los años 2000 a 2006. Memoria de Título, Escuela de Medicina Veterinaria, Universidad Austral de Chile, Vadivia, Chile.

Peloso JG, GD Mundy, ND Cohen. 1994. Prevalence of, and factors associated with musculoskeletal racing injuries of thoroughbreds. J Am Vet Med Assoc 204, 620-626.

Porte E, A Mansilla, J Larroquette. 1994. Análisis del comportamiento deportivo de la raza caballar Criolla Chilena. I. Efectos de sexo, edad y períodos de estudio. Av Prod Anim 19, 139-152.

Ramzan PH, L Palmer. 2011. Musculoskeletal injuries in Thoroughbred racehorses: a study of three large training yards in Newmarket, UK (2005-2007). Vet J 187, 325-329.

Ross MW. 2003a . Lameness in Horses: Basic Facts before Starting. In: Ross MW, Dyson SJ (eds). Diagnosis and Management of Lameness in the Horse. WB Saunders, Philadelphia, USA, Pp 3-7.

Ross MW. 2003 ${ }^{\text {b }}$. Anamnesis (History). In: Ross MW, Dyson SJ (eds). Diagnosis and Management of Lameness in the Horse. WB Saunders, Philadelphia, USA, Pp 9-14.

Scott M. 2008. Musculoskeletal Injuries in Nonracing Quarter Horses. Vet Clin Equine 24, 133-152.

Seitzinger AH, JL Traub-Dargatz, AJ Kane, CA Kopral, PS Morley, LP Garber, WC Losinger, GW Hill. 2000. A comparison of the economic costs of equine lameness, colic, and equine protozoal myeloencephalitis (EPM). Proceedings of the $9^{\text {th }}$ International Symposium on Veterinary Epidemiology and Economics, 1-3.

Smith RK, AE Goodship. 2004. Tendon and ligament physiology. In: Hinchcliff KW, Andris JK, Raymond JG, Warwick B (eds). Equine Sports Medicine and Surgery: Basic and Clinical Sciences of the Equine Athlete. Elsevier Limited, Philadelphia, USA, Pp 130-151.

Stashak TS. 1985. Diagnosis of Lameness. In: TS Stashak (ed). Adams: Lameness in Horses. $4^{\text {th }}$ ed. Lea and Febiger, Philadelphia USA, Pp 100-156.

Stashak TS. 2004 a . Examen de las claudicaciones. En: TS Stashak (ed). Adams: Claudicación en el Caballo. $5^{\mathrm{a}}$ ed. Editorial Inter-Médica, Buenos Aires, Argentina, Pp 113-185.

Stashak TS. 2004 ${ }^{\text {b }}$ Claudicación, El Pie. En: TS Stashak (ed). Adams: Claudicación en el Caballo. $5^{\mathrm{a}}$ ed. Editorial Inter-Médica, Buenos Aires, Argentina, Pp 685-782.

Stewart A. 2011. Equine Metabolic Syndrome. Proceedings of the First International Seminar on Equine Medicine "Neonatology and Metabolic Syndrome”. Universidad Austral de Chile, Valdivia, Chile.

Stock K, H Hamman, O Distl. 2004. Variance component estimation on the frequency of pathologic changes in the navicular bones of Han overian Warmblood horses. J Anim Breed Genet 121, 289-301.

Stricklin JB. 1997. Barrel Racing. AAEP Proceedings 43, 37-39.

Treiber KH, DS Kronfeld, TM Hess, BM Byrd, RK Splan, WB Staniar. 2006. Evaluation of genetic and metabolic predispositions and nutritional risk factors for pasture-associated laminitis in ponies. $J$ Am Vet Med Assoc 228, 1538-1545.

Vergara IS. 2012. Descripción de cascos, herrajes y aplomos en caballos chilenos en la Región de La Araucanía, Temuco-Chile. Memoria de Título, Facultad Silvoagropecuaria, Universidad Mayor, Temuco, Chile.

Wilderjans H, B Boussauw. 2007. Conferencia Internacional de Caballos de Deporte, San José, Costa Rica. 94-103. 